\title{
Guatemala 2018: Facing A Constitutional Crossroad
}

Guatemala 2018: frente a una encrucijada constitucional

\section{KATE BRANNUM}

American Public University System, USA

\begin{abstract}
Guatemalan politics were dominated in 2018 by political strife between the Jimmy Morales administration and the International Commission against Impunity in Guatemala (CICIG). The most pressing issues in Guatemala continue to be corruption and the weakness of the rule-of-law. The year began with but guarded optimism that CICIG could continue its work despite worries about the President's commitment to democracy, but ended with a constitutional crisis that threatened CICIG's work in Guatemala. With general elections approaching in 2019, democracy in Guatemala hangs in the balance. However, at the end of 2018, the makeup of the election was still in doubt and Guatemala was in a constitutional crisis that has not been resolved.
\end{abstract}

Key words: CICIG, Corruption, Constitutional Crisis, Indigenous Rights, Civil Society

\section{RESUMEN}

En 2018, la política guatemalteca fue dominada por los conflictos politicos entre el gobierno de Jimmy Morales y la Comisión Internacional contra la Impunidad en Guatemala (CICIG). Los temas más apremiantes en Guatemala siguen siendo la corrupción y la debilidad del Estado de Derecho. El año comenzó con la preocupación por el compromiso del Presidente con la democracia, pero con un optimismo cauteloso de que la CICIG pudiera continuar con su trabajo, sin embargo, terminó con una crisis constitucional que amenazó el trabajo de la CICIG. Como año previo a las elecciones generales de 2019, el 2018 fue año clave para la democracia guatemalteca. A finales de 2018, la preparación de las elecciones aún estaba en duda, en un contexto de crisis constitucional no resuelto.

Palabras clave: corrupción, crisis constitucional, derechos indígenas, sociedad civil 


\section{INTRODUCTION}

Guatemalan politics was dominated in 2018 by political strife between the Jimmy Morales administration and the International Commission against Impunity in Guatemala (CICIG). This strife is linked to all other major political issues such as protests against the presidency of Jimmy Morales, migration to the US, human-rights issues, and controversy over inadequate preparation for and response to the eruption of the Fuego Volcano. The year began with signs that Morales would more strongly resist CICIG, but guarded optimism that CICIG could continue its work. The year ended, however, with a constitutional crisis that could spell the end of CICIG's progress in reigning in corruption and strengthening the rule-of-law. The corruption crisis has permeated Guatemalan life to the point that the major online journal for political analysis, Nomada Guatemala, has an entire section titled, "Corruption is not normal." The most pressing problem in Guatemala continues to be corruption and the weakness of the rule-of-law, which affects all aspects of politics and society. Guatemalans had hoped that the combination of a president who ran against corruption and the encouraging work of CICIG would lead to continued change. However, 2018 was the year that Morales and his supporters moved to constrain efforts by CICIG to help Guatemalan officials fight against corruption.

\section{BACKGROUND ON CICIG}

The International Commission against Impunity in Guatemala, known by its Spanish acronym CICIG, is funded by the U.N., the United States, and the European Union, and has worked with Guatemalan agencies since 2007 to bring corrupt officials to justice and to help strengthen the rule-of-law. CICIG's mandate allows it to investigate the existence of illicit security forces and clandestine organizations, support the work of Guatemalan institutions (principally the Attorney General), make recommendations to the Government for the adoption of new public policies and procedures, and provide technical assistance to legal institutions, such as the Public Prosecutor's Office and the National Civilian Police (CICIG 2006). CICIG and the Attorney General's Office have investigated corruption in all three branches of government. In connection with the Attorney General's office, they have investigated current and former Congress members, former President Otto Pérez Molina, and former VicePresident Roxana Baldetti, who were arrested on corruption charges in 2015 in a case that involved bribing Guatemalan tax officials for lower import taxes (Elías 2017).

Initially, President Jimmy Morales ran against corruption and refrained from interfering with CICIG activities. However, as anti-corruption activities moved closer to his connections and eventually his family, he became more negative toward CICIG. His lack of cooperation turned to outright opposition after 
CICIG recommended that his brother and son be indicted on corruption charges (Vera 2017).

\section{SOCIAL ISSUES}

Many of Guatemala's social challenges were complicated by continued corruption and weak rule-of-law. Guatemalan society in 2018 was heavily influenced by continued security concerns, the eruption of the Fuego Volcano, and repression of indigenous and human-rights activists. The challenges presented to Guatemala by crime and violence goes far beyond their economic impacts. Every aspect of Guatemalan society is affected by a lack of physical security. Homicide, extortion, narcotrafficking, gang attacks, and other forms of violence continue to be a major issue with the continued strength of organized criminal gangs like Barrio 18 (18th Street) and Mara Salvatrucha (MS13).

There has been steady progress in reducing homicides particularly since CICIG went into full effect. Civilian National Police (PNC) data shows a steady reduction of the homicide rate in Guatemala over the past nine years. According to PNC data, a homicide rate of 47.6 per 100,000 inhabitants in April 2009 fell to 31.3 in April 2014, and 23.5 in June 2018 (IACHR, 2018, 626 ). It is important to note that official Guatemalan police reports only count those that die immediately as homicides; in other words, victims who die of their wounds later are not included in their homicide statistics (IACHR, 2019). However, even though the homicide may be underreported, the trend still holds. The International Crisis Group conducted a study which supported the idea that CICIG has had a strong impact on the decline in homicides. According to the International Crisis Group, homicides declined sharply in Guatemala after CICIG came into existence, while homicide rates continued to rise in a control group (International Crisis Group 2018).

Even with lower homicide rates, the Guatemalan law enforcement and judicial systems have been unable to meet even low expectations when it comes to investigating and prosecuting homicide cases. It has had an extremely low arrest and conviction rate. CICIG reported in 2015 that the impunity rate for homicide was close to 95\% (CICIG 2015). Moreover femicide has actually increased. Guatemala has one of the highest femicide rates in the world (Yagoub, 2016). There were 307 femicides in 2018 (United Nations - 2018. para.12.). Guatemala has taken steps to put in place the appropriate laws. The Law against Femicide and Other Forms of Violence against Women (decree 22-2008) was approved by the Guatemalan Congress in 2008 and has specialized courts at the national level for the prosecution of crimes related to violence against women and femicide. However, despite the creation of these courts, a culture of impunity persists (UNODC 2019 ).

The danger to women and children, along with economic factors, is a major factor in the number of migrants seeking to enter the United States through Mexico 
(Human Rights Watch 2019). The level of violence has also led to vigilantism, particularly in rural areas. Frustrated citizens who see that courts routinely ignore rules for timely trials enact their own form of justice particularly when faced with the inequality of the system. Wealthier prisoners can delay their trials for long periods of time while poorer ones may stay in pre-trial detention for long periods.

One of the ways the Morales administration has responded to high crime rates is to use military police for domestic policing. While military troops were initially requested by various districts, their continued use throughout the year constituted a breach of the wall between civilian matters and military defense especially given that they were used to control crowds during protests (TaftMorales, 2019). In 2017 the Morales administration announced plans to move those troops to border areas (Baires 2017). However, it never fully implemented that plan and continued to use troops in 2018 for domestic policing and control of civil society actions. Their use to control protests against Morales's actions towards the CICIG has been particularly controversial (Isacson 2018).

\section{HUMAN RIGHTS}

According to the 2010 census, 41\% of Guatemalans are Mestizo (Ladino) and $39 \%$ are indigenous. These are the highest percentages in the Americas. The majority of indigenous people in Guatemala are Maya.: K'iche' (11\%), Q'eqchi $(8 \%)$, Kaqchikel (8\%), Mam (5\%), and other Mayan (7.5\%). The indigenous in Guatemala continue to face widespread discrimination and lack of representation. Currently, they are struggling with discrimination in three main areas: land rights, the judicial system, and the killing of indigenous leaders. The next section discusses threats to both human rights defenders in general and indigenous leaders in particular.

The general atmosphere was threatening for Human Rights Defenders in 2018. According to the Human Rights Defenders Unit of Guatemala, there were 391 attacks and 26 killings against human-rights activists in 2018 (OMCT \& UDEFEGUA 2019). Many of those killed were indigenous leaders fighting to protect their lands. Indigenous activists are even more vulnerable than Ladino activists, given that they work in more remote areas and have historically been more likely to be targeted for extrajudicial killings. Indigenous activists continued to speak out about these dangers in 2018. From May 1st to May 10th, 2018, UN Special Rapporteur on the Rights of Indigenous Peoples, Victoria TauliCorpuz, visited Guatemala to examine the situation of the indigenous people and meet with some activists. They reiterated the four types of pervasive racism facing Guatemala's indigenous population: legal, interpersonal, institutional, and structural. The report starts with the statement:

The Special Rapporteur notes that the situation of the Maya, Xinka and Garifuna peoples is characterized by serious structural problems, 
particularly the lack of protection for their rights to their lands, territories and resources and the racial discrimination that pervades all areas of life. She expresses her deep concern at the resurgence of violence, forced evictions and the criminalization of indigenous peoples that defend their rights. Impunity, corruption, institutional weakness, the failure to implement the Peace Agreements and extreme economic and social inequality are the main obstacles. It is imperative that the Government of Guatemala identify the structural problems as a matter of urgency and work towards their resolution. (UN General Assembly, 2018)

As stated in the report, one of the main issues is land and mineral rights. Because indigenous groups have not been granted control of their lands and protection of existing land rights is extremely weak, they are frequently pushed off of their land or have it destroyed by the effects of mining or hydroelectric dams.When this happens, they often have no feasible legal recourse. One of the requirements that the Guatemalan regulatory bodies should be enforcing for the construction of large hydroelectric projects is free, prior, and informed consent for local stakeholders. According to the Commission on Human Rights, Sub-Commission on the Promotion and Protection of Human Rights, Working Group on Indigenous Populations, "Free, prior and informed consent recognizes indigenous peoples' inherent and prior rights to their lands and resources and respects their legitimate authority to require that third parties enter into an equal and respectful relationship with them, based on the principle of informed consent". ${ }^{1}$ Guatemala is a signatory to the 1989 Indigenous and Tribal Peoples Convention, also known as the International Labour Organization's (ILO's) Convention 169, which calls on governments to consult indigenous peoples before permitting exploitation of natural resources on their lands.

Guatemala, like other Central American states, has encouraged the construction of hydroelectric dams, which improve energy independence and reduce carbon output. However, in reality, the cost in terms of land use, access to clean water, and loss of cultural landmarks is borne by the most vulnerable populations in Guatemala: the indigenous. Many of these hydroelectric projects involve incursion on lands that have traditionally been occupied by the indigenous and may involve the destruction of local ecosystems. Fights over mining and hydroelectric dams are not unique to Guatemala; however, the lack of designated comarcas, such as exist in Panama, leave Guatemala's indigenous even more vulnerable.

This year's continued struggle over dams needs to be understood in the context of the 1982 government massacre of indigenous residents connected to the construction of the Chixoy hydroelectric dam, supported by the World Bank and the Inter-American Development Bank (Aguirre 2004). The indigenous 
have organized to struggle against this type of event happening again. Groups like Resistencia Pacifica de Cahabón (Peaceful Resistance Cahabón), which was formed in 2015 in Guatemala to defend the land, water, and rights of indigenous peoples, continued to protest in 2018. Supporters of the mines have responded with violence and by imprisoning protestors. In November of 2018, Bernardo Caal Xól, a representative of the q'eqchí' communities in Santa Maria Cahabón municipality, was sentenced to seven years and four months imprisonment. He was found guilty, based on the testimony of affiliates of the company, of stealing a drill, a tool box, and some fiber-optic cable. He had been representing the indigenous in their efforts to stop hydroelectric projects on the Oxec and Cahabon for which they had not provided consent and which effectively left them without access to water (OHCHR 2018).

Mining is the other major threat to indigenous land rights. Guatemala has been in violation of its obligations under International Labour Organization's Indigenous and Tribal Peoples Convention (ILO 169) by not consistently consulting with indigenous populations. However, in 2018, the courts reaffirmed the 2017 decision to suspend mining operations for several mines after finding a lack of consultation with the Xinca communities. Many people in those communities believe that the mine would be a threat to their ancestral land and water rights. On July 12, 2018, indigenous activist, Ángel Estuardo Quevedo, a member of the Peaceful Resistance in Casillas, which had been advocating for the permanent closure of the Escobal silver mine, was murdered while traveling in Santa Rosa de Lima (Rivera 2018). In September of 2018, the Constitutional Court ruled operations of the Escobal project would remain suspended until the Ministry of Energy and Mines completes a consultation with the local Xinca communities (Garcia 2018). The Escobal mine, which began operations in 2014 is one of the largest silver mines in the world, producing a record 21.3 million ounces of silver in 2016 (Woodin 2018). The controversial Fenix nickel mine also remained closed throughout 2018.

While many of the protests in 2018 by indigenous groups had to do with land and cultural rights, indigenous community leaders have also been focusing more broadly on the rule-of-law and democratic norms. On September 13th, a coalition of "survivors of the internal armed conflict" issued a statement denouncing what they called the re-militarization of Guatemalan society after a press conference in which Morales was surrounded by military officers (NISGUA 2018). They seek to see a strengthening of the rule-of-law that would lead to respect for the rights granted to them under the peace accords and constitution.

Protests by both indigenous and non-indigenous human-rights defenders continued throughout 2018, and were increasingly met by a show of force from the police or the military. For instance, the Unit for the Protection of Human Rights Defenders (UDEFEGUA) reported that a heavy police presence was deployed to human-rights offices in early September, including the Human Rights Office of the Archdiocese of Guatemala (ODHAG), the Association for the Promotion of Security and Democracy (SEDEM), the Committee for Campesino 
Unity (CUC), the Myrna Mack Foundation, and UDEFEGUA (El Observatorio and UDEFEGUA 2018). This police presence is particularly worrisome to human-rights defenders, given the reality of assassinations of human-rights workers over the last several years.

Indigenous leaders sought justice for those recently killed while still awaiting justice for the crimes perpetrated during the civil war. There were a few successes in 2018. On May 23 ${ }^{\text {rd }}$, four former military officials were sentenced to long prison sentences for the disappearance of 14-year-old Marco Antonio, for crimes against humanity, and for aggravated sexual violence committed against Antonio's sister, Emma Guadalupe (CERIGUA 2018). Also, in November of 2018, former soldier Santos López Alonzo, now 66, was found responsible for 171 of the deaths in the Dos Erres massacre of 1982. He was sentenced to 30 years for each; although the total maximum sentence one can serve in Guatemala is 50 years (Soto 2018). While this was good news for survivors and indigenous activists, the time it took to reach this stage was very frustrating, especially given that others who have been accused have died of natural causes before having to face justice. According to a United Nations truth commission, about 200,000 people were killed and 45,000 disappeared during the conflict.

Along with the murder of human-rights activists, there have been deep concerns with the murder of journalists. Guatemala was ranked 116th in the world, in terms of press freedom by the Reporters without Borders World Press Freedom Index. The year began with the arrest of lawmaker, Julio Antonio Juarez Ramirez, for contracting out the murder of two journalists in 2015: Danilo Zapón López, of Prensa Libre, and Federico Salazar, of Radio Nuevo Mundo (Nalvarte 2018). On February 1st, the bodies of Laurent Ángel Castillo Cifuentes and Luis Alfredo de León Miranda were discovered in Guatemala's southwestern Suchitepéquez department (Morales and Miranda Rolando 2018).

\section{VOLCANO RESPONSE}

Another major event that led to social discord was the eruption of the Fuego Volcano on June 3rd. Small eruptions of this volcano are common and a larger one was not unexpected. However, in the aftermath there were questions about preparation, evacuation, response, shelter, and recovery of bodies. The number of dead from the eruption is uncertain. By the end of 2018, official numbers were at 159 people, with 260 still missing. These numbers are hotly disputed by volunteer groups like Antigua al Rescate, who believe the death toll was much higher. In July 2018, this group argued that the total number of people killed or missing was closer to 2,900 (Dominguez 2018). Whatever the true numbers are, the large gap in estimates illustrates the lack of precision and trust on the ground.

While the government's response to the volcano eruption has not gotten a lot of attention outside of Guatemala, it is an intense issue within Guatemala, 
particularly in affected areas. Groups like Antigua al Rescate and even local firefighters found ways to send aid directly to the survivors because they did not trust that any goods or money collected by the government would ever make it to them. This distrust is in line with the perception of corruption in Guatemala in general. According to Transparency International's Corruption Perception Index, Guatemala's score is 27 out of 100 and it ranks $144^{\text {th }}$ out of 180. One of the major points of contention besides the number of victims was why the government had not evacuated the area in time to prevent the high death toll.Thousands of people protested in the streets the next week, demanding an investigation (RTVE 2018).

Another major issue was the quantity and quality of help available to survivors. Less than a quarter of the people were housed in the shelters, and those shelters did not meet international standards. Most of the food and water came from individual volunteers and groups.

Jimmy Morales made matters worse when he announced "I'm ashamed of saying this again, but according to our budget law, we can't have a single penny. The budget law doesn't allow the state to spend a penny on emergencies" (Telesur 2019). The National Coordination for Disaster Reduction of Guatemala (CONRED) and the local firefighters are grossly underfunded. Most firefighters are volunteers and most stations get a very small stipend from the government and rely on donations collected on street corners and larger donations from abroad.

\section{ECONOMY}

Guatemala's economy, which is the largest in Central America, grew by 3.0 percent in 2018 marking a 3.0 growth rate since 2012. The World Bank predicts this will continue into 2019 (World Bank 2019). However, there are underlying problems that indicate that this will not lead to greater societal wellbeing and coherence. The World Bank also reports that more than half of the population is below the national poverty line, with $23 \%$ living in extreme poverty. Poverty among indigenous groups, which make up more than $40 \%$ of the population, averages $79 \%$, with $40 \%$ living in extreme poverty. Nearly one-half of Guatemalan children under age five are chronically malnourished-one of the highest malnutrition rates in the world. Guatemala also has one of the highest inequality rates in the region with no indication that reform is on the way. It ranks 127th out of 189 on the 2018 Human Development Index (Congressional Research Service 2019).

A continuing problem is the lack of investment in infrastructure and social programs. Part of the problem is that Guatemala has the lowest tax-to-GDP ratio in the region. This is due in part to the high rate of employment in the informal economy-the Instituto Nacional de Estadística reports 71\% of the population held informal employment in 2018 (Instituto Nacional de Estadística 
Guatemala 2019). The IMF noted in its report in June 2018 that Guatemala needed to increase spending on infrastructure and social issues to $15 \%$ of GDP to lift more Guatemalans out of poverty. It notes this would require tax reform (IMF 2018). However, efforts to reform taxes have been stymied by corruption and the President's hostility to supporters of CICIG. The crisis around CICIG and Morales has mean that tax reforms and infrastructure projects have been put on hold despite initial efforts by Morales appointees. For example, Juan Francisco Solórzano, leader of the tax administration, was working to reform the administration and to bring in more money but was fired by Morales in January 2018 (Dudley 2018).

In addition, long-term economic security is threatened by continuing violence and crime. Tourism could be much stronger considering that Guatemala has many areas which are natural tourist attractions. However, warnings and travel advisories like the one the US State Department published in 2018 discourage tourism from the U.S. In 2018 the US State Department travel warning advised, "Exercise increased caution in Guatemala due to crime" and recommended that people reconsider travel to the departments of: Guatemala, Escuintla, Chiquimula, Quetzaltenango, Izabal and Petén.

Guatemalan officials have had some success in keeping tourist areas such as Antigua, Sololá, and Lake Atitlan safe for tourists. According to the National Board of Tourist Assistance (PROATUR), there were 195 recorded instances of crimes against tourists in Guatemala in 2018 out of the 2.4 million registered tourists who visited the country during the year (OSAC 2019). Antigua attracts more than 500,000 people for its Holy Week processions. Lake Atitlan also attracts people from all over the world. However, even tourism in safe areas is damaged by Guatemala's overall reputation.

\section{POLITICS}

The underlying but always present political schism between status-quo and reformist actors came to the surface in 2018 and dominated the political scene. Despite the efficacy of some of CICIG's efforts, or perhaps because of that efficacy, the Jimmy Morales administration, which had become increasingly less cooperative even in 2017, began to actively oppose its work. The president's desire to put an end to CICIG's prosecutions was shared by the Comité Coordinador de Asociaciones Agrícolas, Comerciales, Industriales y Financieras (CACIF). Many members of this powerful group of private-sector supporters were targets of the investigation or had relatives who were. On August $10^{\text {th }}$, prosecutors called for Congress to strip the President's immunity so that he could be prosecuted for corruption and for challenging the Maduro regime in Venezuela. Morales accused CICIG of "selective criminal prosecution on ideological grounds, using a distorted interpretation of national norms and of its own mandate." (Guatemalan presidents cannot be prosecuted unless the Supreme Court and 
two-thirds of Congress give their consent.). Congress voted against stripping his immunity. A few weeks later, on August 31 ${ }^{\text {st }}$, Morales, already angered by investigations of his family, announced that the CICIG charter would not be renewed when it expires in September 2019.

The real political crisis came on September $4^{\text {th }}$, when President Morales banned CICIG Commissioner, Ivan Velasquez, from reentering the country. He made the announcement surrounded by military officials, which attracted a great deal of commentary in the press. As one Nomada commentator wrote, "He resurrected all the ghosts of the military state coups and sent military vehicles to the streets to intimidate citizens, civil society organizations, the CICIG and the US Embassy" (Woltke 2018). One of Morales's ministers resigned rather than carry out the order (Congressional Research Service 2019). On September 16th, the constitutional court ruled that Ivan Velasquez had to be let back into the country. However, the Morales administration ignored the order, thus creating a constitutional crisis. This breech of Guatemala's constitution has brought about condemnation from both domestic and international bodies. The condemnation been met with defiance from the Morales administration. (Pellecer 2018) On September $17^{\text {th }}$, Enrique Antonio Degenhart Asturias, Minister of the Interior and Home Affairs, reiterated the administration's position, stating in a press conference that "Colombian citizen Ivan Velasquez will not enter the country" (Pérez 2018).

The situation worsened from there. On December 18th, 11 other CICIG employees were ordered to leave the country within 72 hours (Menchu 2018). Later in December, the attacks against those that supported CICIG continued with threats to use corruption law as a way to actually attack those supporting the fight against corruption. At the end of the year, on December $26^{\text {th }}, 2018$, there were threats from the State's attorney's office to take away the judicial immunity of three Constitutional Court justices who had ruled against Morales on CICIG cases. They presented a pre-trial request to begin the process (NISGUA 2019).

President Morales also withdrew police protection from CICIG officials. In total, since 2017, the Guatemalan government has withdrawn almost two-thirds of the police officers originally assigned to the international commission (El Periódico de Guatemala 2019). The other main area of attack has been the use of social media trolls or "netcenteros" who were part of a campaign against CICIG. Despite the potential dismantling of CICIG, some of its court cases continued in the autumn of 2018. On October $9^{\text {th }}, 2018$, a court found several of the highestranking officials in the country guilty of unlawful association, corruption, and fraud in relation to a project to clean up pollution in Lake Amatitlán. Two weeks earlier, a network of officials at the Guatemalan Social Security Institute were arrested for theft in the irregular procurement of dialysis services for patients with kidney disease, which resulted in the deaths of more than 50 people.

Meanwhile, on November $23^{\text {rd }}$, Ivan Velasquez and Sandra Aldea were awarded the 2018 Right Livelihood Award "for their innovative work in exposing abuse 
of power and prosecuting corruption, thus rebuilding people's trust in public institutions." "One widely held point-of-agreement among Guatemalans is that the CICIG is doing good work. . A 2017 poll taken by Nomada found that more than $72 \%$ of the population has little to no trust in the police, and about $65 \%$ have little to no trust in the government, but $83 \%$ of the population said they supported CICIG and the Public Ministry-which is headed by the attorney general-making these Guatemala's most trusted institutions (Pellecer 2017). However, those in power can withstand the pressure from the general public as long as CICIG opponents continue to hold powerful places in business, the executive, the Congress, and even the judiciary.

\section{INTERNATIONAL RELATIONS}

The two main issues between the United States and Guatemala in 2018 were CICIG and migration. President Jimmy Morales and others who opposed CICIG sought to pursue good relations with the Trump administration to prevent pressure from the US to cooperate with CICIG. In 2017, a group of Guatemalan business leaders, who support Jimmy Morales in his struggle against CICIG, hired a U.S. lobbying firm, Barnes \& Thornburg LLP, to shift US opinion in favor of the Morales administration and against CICIG. A second contract with this firm was signed on May $17^{\text {th }}$ by four Guatemalan congressmen. President Morales also did his best to be seen as a Trump supporter by backing Trump's policy towards Israel. The Guatemalan embassy was moved to Jerusalem, and President Morales even traveled there to celebrate (Estrada 2018). In February 2018, Trump met with Morales in Washington, thanking him for his support of Israel.

Lukewarm US support for CICIG was also demonstrated when US Senator Marco Rubio suspended funding to CICIG after false claims that CICIG had been infiltrated by Russians. At the time he tweeted, "We have placed a hold on CICIG funding to provide time to conduct more oversight over if \&/or how this U.N. organization funded by U.S. taxpayers coordinated with sanctioned Russian bank to persecute the Bitkov family". He later restored funding after being confronted with evidence that there was no Kremlin interference (Gedan 2019).

However, suspicions toward CICIG remained strong within the US Republican party. Unlike during a previous attempt by Otto Pérez Molina to discontinue CICIG, Morales's actions in May 2018 did not result in meaningful counterpressure from the U.S. The Trump administration did not express strong support for CICIG or its commissioner after he was barred from re-entering the country. Secretary Pompeo spoke with President Morales on September 6th, 2018, expressing continued support for "a reformed CICIG," but it was unclear what that actually meant. However, European states continued to support CICIG and condemn Morales's actions. For example, Sweden condemned Morales after he 
announced that he would end CICIG. This drew a swift rebuke from Morales, however: Sweden's ambassador, Anders Kompass, was told in early May to leave Guatemala within 30 days for allegedly intervening in domestic affairs (Lakhani 2018)."

Despite good relations with the Trump administration and a new U.S ambassador taking a much more sympathetic view towards the Morales administration, the issue of migration created a crisis between Guatemala and the US, with the Trump administration threatening to cut off aid to Guatemala if more was not done to stop migration to the US (Silva and Álvarez 2018). The Trump administration continued to claim a crisis on the border, creating a zero-tolerance' policy which included prosecuting all border-crossers and making asylum claims extremely difficult. During the first nine months of 2018, Guatemalans made 5,000 affirmative asylum claims. (Meissner et. al. 2018)

The situation with migration was further complicated with migrant caravans being stuck between Guatemala and Mexico (EuroNews 2018). Civil society got involved in trying to provide some help to the migrants, including taking resources that were collected for volcano relief and using them to help people in the migrant caravans. Tension within Guatemala was further stoked by the death of two Guatemalan children in U.S. Customs and Border Protection custody in December 2018.

\section{ELECTIONS}

The president is elected in a two-round system. Thirty-one members of Congress are elected through a national list, while the remaining members are elected through districts comprised of around 80,000 voters. Active members of the armed forces and police are not allowed to vote. Guatemala has a multiparty system which can still be described as somewhat chaotic. It has a large number of parties with none being totally dominant. Politics is driven more by the followings of particular politicians rather than strong party loyalty. Major political parties in Guatemala include the Democratic Union, the Grand National Alliance, and the Encounter for Guatemala, the National Unity of Hope, and Winaq. Interestingly, no single party in Guatemala has elected a president more than once since the end of the civil war.

The first round of the Presidential, Congressional, and mayoral elections will be June 16th, 2019. If no candidate wins a majority in the first round, a second round of the presidential elections will be held on August 11th, 2019. One of the most remarkable aspects of this election is the role played by accusations of current or past criminality. At the end of 2018, the makeup of the election was still in doubt. For instance, the US DEA began investigating candidate Mario Estrada. Candidate Sandra Torres was also under investigation by Guatemalan prosecutors during what was her third attempt for the presidency. She finished second in 2015, after divorcing her husband, former President Álvaro Colom, in 
an attempt to avoid the constitutional bar on the spouses of sitting presidents running, which prevented her from seeking the office in 2011.

As of December 2018 the following were declared candidates (Pocasangre 2018b):

- Partido Pan y Podemos: Roberto Arzú García-Granadoz

- Partido Victoria: Amilicar Rivera

- El Partido Humanista: Edmond Mulet

- Prosperidad Ciudadana: Edwin Escobar

- Partido Avanza: Danilo Roca

- Partido Viva:Isaac Farchi

- Movimiento para la Liberación de los Pueblos: Thelma Cabrera

- Semilla: Thelma Aldana

\section{Executive Branch}

The current president was elected to a four-year term in 2015. Term limits only allow one-term for the president and vice-presidents have to be out of office for at least four years before being eligible to run for president. The spouses of sitting presidents are also banned from running.

As Morales has become less tolerant of CICIG in the second half of 2017 and in 2018, his cabinet has changed drastically due to both resignations and firings. At the end of 2017, Morales changed his ministers for the environment, the economy, and social development. In September 2017, the ministers of labor and social services, interior, and finance all announced their resignations (Albaladejo 2017). Their stated reason was the continuing "political crisis," which did not allow them to fulfill their responsibilities to the Guatemalan people. In January 2018, Acisclo Valladares took over as Economic Minster from Victor Asturias, while Alcides Obregon replaced Enio Galicia at social development, and Alonzo Vargas replaced Sydney Samuels in environment (Pocasangre 2018).

In January 2018, Juan Francisco Solórzano, leader of the tax administration and someone who was important in the struggle against corruption, was fired by Morales. Degenhart was sworn in as Minister of the Interior in January 2018, after his predecessor, Francisco Rivas, was fired by the president and subsequently fled the country to avoid arrest. In February 2018, Morales fired three top police officials, despite criticism from various elements of civil society (Congressional Research Service 2019). In May 2018, Maria Consuelo Porras became the newly appointed Attorney General to replace Thelma Aldana. 


\section{Judicial Branch}

The two highest courts in Guatemala are the Supreme Court of Justice and the Guatemalan Constitutional Court. The Supreme Court of Justice is composed of thirteen members, who serve five-year terms. They elect a president of the Court each year from among their numbers. The President of the Supreme Court of Justice is also the supervisor of all Guatemalan trial judges. The key player in the constitutional crisis of 2018 was the Guatemalan Constitutional Court, which was established in 1985 for the purpose of ruling on constitutional issues. There are five justices serving five-year terms. One is elected by Congress, one by the Supreme Court of Justice, one elected by Superior Council of the Universidad San Carlos de Guatemala, one by the Bar Association (Colegio de Abogados), and one is appointed by the President. The Constitutional Court has no enforcement mechanisms, and it is unclear how the police and military would react if the Court asked for assistance in the current constitutional crisis.

\section{Legislative Branch}

Guatemala has a unicameral legislature system with 158 deputies elected to four-year terms. All are up for election in 2019. Thirty one deputies are elected on a nationwide ballot and 127 are elected from 22 districts. Members of indigenous communities hold only 20 seats, although they constitute $40 \%$ of the population. Congress, which does not have a quota system, has only 30 female members (Inter-Parliamentary Union.2019). The functioning of Congress has been seriously constrained by the fact that its members are focused on CICIG and face potential arrest. Almost half of the members of Congress face the possibility of corruption charges (Congressional Research Service 2019). On September $13^{\text {th }}, 2018$, the Guatemalan Congress passed a "national emergency" bill to weaken anti-corruption election laws. However, they repealed it two days later due to public pressure.

The two most worrisome issues when it comes to the functioning of the political structure of Guatemala is the fact that Morales has simply ignored a Supreme Court ruling that Ivan Velasquez had to be let back into the country without facing any sustained action from the legislative branch. Members of Congresses have also been suffering from the anti-corruption investigations and may have seen it in their best interest to allow Morales to debilitate CICIG. 


\section{State of Democracy}

With general elections approaching in 2019, the democracy in Guatemala is in the balance. In 2018, the Guatemalan government stopped operating within the constraints of its own constitution, precipitating a constitutional crisis that has not yet been resolved. The country is not, at this point, a full, stable democracy. For 2018, the Economist Intelligence Unit gave Guatemala the status of "hybrid democracy," with its score going down for the third year in a row going down from 586 to 560. Similarly, Freedom House labeled Guatemala as Partly Free. Guatemalan democracy can only be secured with a strong commitment to the rule-of-law, and adherence to the constitution. While elections are relatively free, the decision of who is allowed to run is heavily influenced by criminal charges and countercharges rather than qualifications. Intimidation and violence at the polls also impact the quality of Guatemalan elections. The most profound issue, however, is the corrupt financing of elections that gives an advantage to candidates with wealthier backers. \

\section{CONCLUSION}

2018 was a perilous year for Guatemala. The country, which had been teetering on the edge for some time, fell right into a constitutional crisis after the president refused to reverse his ban against Ivan Velasquez re-entering the country, despite an order to do so by the Constitutional Court of Guatemala. It is unclear at this point whether Guatemalan democracy can get back on its feet and once again focus on demilitarizing and ending corruption. Whether the shows of military force at press conferences, peaceful protests, and the CICIG headquarters signal a long-term slide back toward militarization and full impunity for corruption is the main question we bring forward from 2018.

\section{REFERENCES}

Aguirre, Monti. 2004. “The Chixoy Dam Destroyed Our Lives." Human Rights Dialogue, Environmental Rights, Spring 2004. Retrieved 31 May 2019 from https:/ /www.carnegiecouncil.org/publications/archive/dialogue/2_11/section_3/4456.

Albaladejo, Angelika. 2017, September 20. "Guatemala Corruption Crisis Deepens With Cabinet Resignations, National Strike." InSight Crime, 2017. Retrieved 15 July 2019 from https://www.insightcrime.org/news/brief/guatemala-corruption-crisis-deepens-cabinet-resignations-national-strike/.

Baires, Lorena. 2017, April 4. "Guatemala reforzará sus fronteras para cortar rutas de narcotráfico." Dialogo, Retrieved 15 July 2019 from https:/ /dialogo-americas.com/es/ articles / guatemala-shore-its-borders-cut-drug-trafficking-routes.

Boyette, Laura. 2019. 11 April. "Creating a Culture of Peace in Guatemala | Democracy Speaks." Democracy Speaks. Retrieved 15 July 2019 from https://www.democracyspeaks.org/blog/creating-culture-peace-guatemala.

Castaño, Lucía. 2018, December 3. “Entrevista a Iván Velásquez: ‘Luchar Contra La Corrupción Es Luchar Contra La Pobreza Que Genera." El Tiempo, Retrieved 15 July 
2019 from https://www.eltiempo.com/mundo/europa/entrevista-a-ivan-velasquez-luchar-contra-la-corrupcion-es-luchar-contra-la-pobreza-que-genera-300156.

CERIGUA. 2018, May 25. "Sentencia en el caso "Molina Theissen, un 'Precedente Importante Para La Justicia Guatemalteca': IW", Retrieved 15 July 2019 from https: / / cerigua.org/ article/sentencia-en-el-caso-molina-theissen-un-precedente/

Chumil, Katerin. 2019, January 23. “Gobierno Notifica a CICIG Sobre El Retiro de Patrullas y Policías." El Periódico de Guatemala, Retrieved 15 July 2019 from https:/ /elperiodico.com.gt/nacion/2019/01/23/gobierno-notifica-a-cicig-sobre-el-retiro-de-patrullas-y-policias/.

CICIG 2006. Acuerdo entre la Organización de Naciones Unidas y el Gobierno de Guatemala relativo al Establecimiento de una Comisión Internacional Contra La Impunidad en Guatemala (CICIG). https://www.cicig.org/uploads/documents/mandato/cicig acuerdo.pdf

CICIG. 2015. Sistema de la mediación de la impunidad en Guatemala. Comisión Internacional Contra la Impunidad en Guatemala. Retrieved 14 August 2019 from https://cicig.org/ uploads/documents/2015/Docto_SisMedImp_20160414.pdf

Congressional Research Service. 2019. Guatemala: Political and Socioeconomic Conditions and U.S. Relations. Retrieved 14 August 2019 from https:/ fas.org/sgp/crs/row/R42580.pdf

Cuffe, Sandra. 2018, September 16. "'Resign!': Protests against Jimmy Morales Mount in Guatemala amid Constitutional Crisis." Los Angeles Times. Retrieved 14 August 2019 from https://www.latimes.com/world/mexico-americas/la-fg-guatemala-crisis-20180916-story.html.

Dominguez, Andrea. 2018, July 4. "Antigua al Rescate: Son 2,900 son los desaparecidos o fallecidos, no 332 como dice el gobierno." Guatevisión, Retrieved 15 July 2019 from https:/ / www.guatevision.com/noticias/nacional/antigua-al-rescate-son-2900-sonlos-desaparecidos-o-fallecidos-no-332-como-dice-el-gobierno/.

Dudley, Steven. 2018, January 24. "With Firing of Tax Agency Chief, Guatemala's Status Quo Makes Its Move." InSight Crime. Retrieved 15 July 2019 from https://www.insightcrime.org/news/analysis/guatemalas-status-quo-makes-its-move/

El Observatorio \& UDEFEGUA. 2018, September 6. “Guatemala: Comunicado conjunto: Clima de intimidación contra la sociedad civil tras la lamentable decisión de no renovar el mandato de la CICIG". Retrieved 15 July 2019 from https://www.omct.org/es/ human-rights-defenders/urgent-interventions/guatemala/2018/09/d25023/

Elías, José. 2017, October 28. “El expresidente de Guatemala Otto Pérez será juzgado por corrupción." El País. Retrieved 15 July 2019 from https://elpais.com/internacional/2017/10/28/america/1509150756_258596.html.

Estrada, Javier. 2018, May 16. “El dueño del Avión en el que se fue Jimmy a Israel ha sido sancionado por corrupción en el extranjero."Nomada. Retrieved 15 July 2019 from https://nomada.gt/pais/la-corrupcion-no-es-normal/el-dueno-del-avion-en-el-quese-fue-jimmy-a-israel-ha-sido-sancionado-por-corrupcion-en-el-extranjero/.

EuroNews. 2018, October 20. "Thousands of People Stuck Between Guatemala and Mexico." Retrieved 15 July 2019 from https://www.euronews.com/2018/10/20/thousands-of-people-stuck-between-guatemala-and-mexico

Flores, Pia and Gabriel Woltke. 2018, April 11. “Russian 'Fake News' Against the CICIG Has a Dark Origin in a Case That Reaches Minister Degenhart." Nomada. Retrieved 15 July 2019 from https://nomada.gt/pais/la-corrupcion-no-es-normal/russian-fake-newsagainst-the-cicig-has-a-dark-origin-in-a-case-that-reaches-minister-degenhart/.

Garcia, David Alire. 2018, December 24. "Conflicto minero en guatemala inquieta a la industria en toda latinoamérica." Retrieved 15 July 2019 from https:/ / lta.reuters.com/articulo/mineria-guatemala-idLTAKCN1ON10B-OUSLT

Gedan, Benjamin N. 2018, September 6. "The U.S. Decision to Abandon CICIG in Guatemala Doesn't Make Moral or Geostrategic Sense." Global Americans. Retrieved 15 July 2019 from https:/ / theglobalamericans.org/2018/09/the-u-s-decision-to-abandon-cicig-inguatemala-doesnt-make-moral-or-geostrategic-sense/. 
Human Rights Watch. 2019, December 20. “World Report 2019: Rights Trends in Guatemala." Human Rights Watch. Retrieved 15 July 2019 from https:/ /www.hrw.org/world-report/2019/country-chapters/guatemala.

IACHR.2018. Annual Report. Inter American Comission on Human Rights. Retrieved 30 May 2019 from https://www.oas.org/en/iachr/docs/annual/2018/TOC.asp.

IMF. 2018, June 18. "Guatemala: More Investment and Social Spending Needed." IMF Country Focus. Retrieved 30 May 2019 from https://www.imf.org/en/News/ Articles/2018/05/30/NA060118-Guatemala-More-Investment-and-Social-Spending-Needed.

Instituto Nacional de Estadística Guatemala. 2019. Estadística: Tema/Indicadores. Retrieved 8 February 2019 https:/ /www.ine.gob.gt/index.php/estadisticas/tema-indicadores

Inter-Parliamentary Union. 2019. "Women in national parliaments". Retrieved 15 July 2019 from http://archive.ipu.org/wmn-e/classif.htm

International Crisis Group. 2018. Saving Guatemala's Fight Against Crime and Impunity. International Crisis Group, Report 70. Retrieved 15 July 2019 from https://www.crisisgroup.org/latin-america-caribbean/central-america/guatemala/70-saving-guatemalas-fight-against-crime-and-impunity.

International Labor Office. 1991. "International Labour Organization's Indigenous and Tribal Peoples Convention." Entry into force: 05 Sep 1991. Retrieved 15 July 2019 from https://www.ilo.org/dyn/normlex/en/f?p=NORMLEXPUB:12100:0::NO::P12100_ ILO_CODE:C169

Isacson, Adam. 2018, September 24. "Guatemala's Military Shows Aggressive Support for CICIG Backlash." Retrieved 15 July 2019 from https:/ /www.wola.org/analysis/guatemala-army-cicig-backlash/.

Lakhani, Nina. 2018, May 17. "Corrupt Guatemalan Officials Find Help from an Unlikely Source: Marco Rubio." The Guardian. Retrieved 15 July 2019 from https://www. theguardian.com/world/2018/may/17/guatemala-marco-rubio-corruption.

Meissner, Doris, Hipsman, Faye, and Aleinikoff, T. Alexander. 2018. The U.S. Asylum System in Crisis: Charting a Way Forward. Migration Policy Institute. Retrieved 15 July 2019 from https://www.migrationpolicy.org/research/us-asylum-system-crisis-chartingway-forward

Menchu, Sofia. 2018, December 18. “Guatemala Expels Investigators from U.N. Anti-Corruption Group." Reuters. Retrieved 15 July 2019 from https:/ / www.reuters.com/article/ us-guatemala-politics-idUSKBN1OH2A6

Monzón, Kenneth. 2019, April 16. “Tribunal Absuelve a Abelino Chub Caal y Ordena Su Libertad Inmediata - Prensa Libre." Prensa Libre. Retrieved 15 July 2019 from https:/ / www. prensalibre.com/guatemala/justicia/tribunal-absuelve-a-abelino-chub-caal-y-ordena-su-libertad-inmediata /

Morales, Sergio, and Miranda, Rolando. 2018, February 3. "Familiares y amigos piden justicia durante el sepelio de los periodistas Laurent Castillo y Luis de León." Prensa Libre. Retrieved 15 July 2019 from https://www.prensalibre.com/ciudades/sip-condena-asesinato-de-periodista-laurent-angel-castillo-y-trabajador-de-emisora-radial-luis-alfredo-de-leon-miranda/.

Nalvarte, Paola. 2018, January 17. “Guatemalan Congressman Arrested, Accused of Being Mastermind behind Murder of Two Journalists in 2015." Knight Center for Journalism in the Americas Retrieved 15 July 2019 from https://knightcenter.utexas.edu/ blog/00-19197-guatemalan-congressman-arrested-accused-being-mastermind-behind-murder-two-journalists.

NISGUA. 2018, September 13. "Survivors of the Internal Armed Conflict Denounce Current Remilitarization - NISGUA." Network in Solidarity with the People of Guatemala. Retrieved on 15 July 2019 from: https://nisgua.org/survivors-denounce-current-remilitarization/.

NISGUA. 2019, January 9. "Political Crisis Continues in Guatemala: A Timeline." Retrieved on 15 July 2019 from https:/ /nisgua.org/political-crisis-continues-guatemala-timeline/ 
OHCHR. 2018, December 19. “Guatemala: UN Experts Concerned Indigenous Leader Convicted in Retaliation for Opposition to Oxec Hydro Project." Retrieved 15 July 2019 from https://www.ohchr.org/en/NewsEvents/Pages/DisplayNews.aspx?News$\mathrm{ID}=24031 \&$ LangID $=\mathrm{E}$.

OMCT and UDEFEGUA. 2019, March 4. "Impunity and siege on civil society mark human rights crisis in Guatemala." World Organization Against Torture (OMCT) \& Union for the Protection of Human Rights Defenders in Guatemala (UDEFEGUA). Retrieved 15 July 2019 from https:/ / pbiusa.org/OMCT_UDEFEGUA_pressrelease

OMCT. 2018. "Intervenciones Urgentes / Defensores de derechos... / OMCT." Retrieved 15 July 2019 from http://www.omct.org/es/human-rights-defenders/urgent interventions/guatemala/2018/09/d25023/.

OSAC 2019. “Guatemala 2019 Crime \& Safety Report." Retrieved 29 May 2019 from https:/ / www.osac.gov/Content/Report/5f31517e-62bb-4f2c-8956-15f4aeaab930

Paredes, Luisa. 2018, September 22. "PDH y organizaciones condenan asesinato de la lideresa Juana Ramírez Santiago". El Periódico. Retrieved 15 July 2019 from https:/ / elperiodico.com.gt/nacion/2018/09/22/pdh-y-organizaciones-condenan-asesinato-de-la-lideresa-juana-ramirez-santiago/

Pellecer, Martín Rodríguez. 2017, March 27. “Encuesta: Pro MP-CICIG y democracia, y no por gobierno, Cacif y Ejército." Nómada. Retrieved 15 July 2019 from https:/ /nomada.gt/ pais/encuesta-pro-mp-cicig-y-democracia-y-no-por-gobierno-cacif-y-ejercito /

Pellecer, Martín Rodríguez. 2018, September 21. "Jimmy Morales da un paso más en la amenaza de quebrar el orden constitucional." Nómada. Retrieved 15 July 2019 from https:/ / nomada.gt/pais/la-corrupcion-no-es-normal/jimmy-morales-da-un-paso-mas-en-laamenaza-de-quebrar-el-orden-constitucional/

Pérez, Sonia, D. 2018, 18 September. "Guatemala Govt Bars Anti-Graft Chief, Defying Court Ruling." AP NEWS. Retrieved 15 July 2019 from https://apnews.com/de745da7acb14619 bcdd786f84b40271

Pocasangre, Henry Estuardo. 2018a, January 16. "Gobierno cambia a los ministros de Economía, Desarrollo Social y Ambiente." Prensa Libre. Retrieved 15 July 2019 from https://www.prensalibre.com/guatemala/politica/destituyen-al-ministro-de-desarrollo-ennio-galicia/.

Pocasangre, Henry. 2018b. "Candidatos a presidente de Guatemala en las elecciones 2019." República. Retrieved 15 July 2019 from https://republica.gt/2018/12/10/candidatos-a-presidente-de-guatemala-2019/

Reporters Without Borders. 2019. 2019 World Press Freedom Index. Retrieved 15 July 2019 from https:/ /rsf.org/en/ranking\#

Rivera, Nelton. 2018, July 12. “Asesinaron a Ángel Estuardo Quevedo opositor a la minera San Rafael." Prensa Comunitaria. Retrieved 15 July 2019 from https: / / www.prensacomunitaria.org/asesinaron-a-angel-estuardo-quevedo-opositor-a-la-minera-san-rafael1/.

RTVE. 2018, June 10. "Piden la renuncia del presidente de Guatemala mientras el volcán sigue amenazante." Retrieved 15 July 2019 from http://www.rtve.es/ noticias / 20180610/piden-renuncia-del-presidente-guatemala-mientras-volcan-sigue-amenazante/1748640.shtml

Silva, Daniella, and Christopher Álvarez. 2018, October 16. "Migrant Caravan Heads North as Trump Threatens to Stop Aid to Honduras." NBC News. Retrieved 15 July 2019 from https:/ / www.nbcnews.com/news/latino/migrant-caravan-heads-north-trumpthreatens-stop-aid-honduras-n920806

Solano, Francelia. 2018, June 3. "Jimmy Morales: "La ley de presupuesto no contempla que el Estado pueda gastar un centavo en emergencias." Plaza Pública. Retrieved 15 July 2019 from https://www.plazapublica.com.gt/content/jimmy-morales-la-ley-de-presupuesto-no-contempla-que-el-estado-pueda-gastar-un-centavo-en

Soto, Luis. 2018, November 23. "Ex-Soldier Gets 5,160 Years in Prison for Guatemala Massacre." The New York Times. Retrieved 15 July 2019 from https://www.ny- 
times.com/2018/11/22/world/americas / guatemala-soldier-massacre-santos-lopez-alonzo.html.

Taft-Morales, Maureen. 2019. "Guatemala: Political and Socioeconomic Conditions and U.S. Relations." Congressional Research Service. Retrieved 15 July 2019 from https:/ / fas. $\mathrm{org} / \mathrm{sgp} / \mathrm{crs} / \mathrm{row} / \mathrm{R} 42580 . \mathrm{pdf}$

Telesur. 2019, June 10. "Thousands of Guatemalans Protest President Morales, Demand His Resignation Over Fuego Volcano Crisis." TeleSUR. Retrieved 15 July 2019 from https://www.telesurenglish.net/news/Thousands-of-Guatemalans-Protest-President-Morales-Demand-His-Resignation-Over-Volcano-Crisis-20180610-0006.html.

U.S. Department of State. 2018, September 6. "Secretary Pompeo's Call with Guatemala President Jimmy Morales." Press Release. Retrieved 15 July 2019 from https: / / www.state. gov/r/pa/prs/ps/2018/09/285757.html

U.S. State Department. 2019. "Guatemala Travel Advisory." Retrieved 15 July 2019 from https://travel.state.gov/content/travel/en/traveladvisories/traveladvisories/guatemala-travel-advisory.html

International Covenant on Civil and Political Right. 2018. Concluding Observations on the fourth periodic report of Guatemala, Human Rights Committee. CCPR/C/GTM/CO/4United Nations.

United Nations, General Assembly. 2018. Report of the Special Rapporteur on the Rights of Indigenous Peoples on Her Visit to Guatemala. A/HRC/39/17/Add.3. Retrieved 15 July 2019 from http://unsr.vtaulicorpuz.org/site/index.php/en/news/notes/250-report-guatemala

UNODC. 2019. Global Study on Homicide. United Nation Office on Drugs and Crime. Retrieved 15 July 2019 from https://www.unodc.org/unodc/en/data-and-analysis/global-study-on-homicide.html.

UNSR. 2018. "Report of the Special Rapporteur on the Rights of Indigenous Peoples on Her Visit to Guatemala." Retrieved 30 May 2019 from http://unsr.vtaulicorpuz.org/site/ index.php/en/news/notes/250-report-guatemala.

Vera, Asier. 2017, January 18. "La juez envía a prisión al hermano y al hijo del presidente de Guatemala por un caso de corrupción." El Mundo. Retrieved 15 July 2019 from https://www.elmundo.es/internacional/2017/01/18/587fd8c4468aeb58638b460b. html.

WOLA. 2019. "CICIG: Text of the Agreement between the United Nations and the State of Guatemala on the Establishment of an International Commission against Impunity in Guatemala." Retrieved 15 July 2019 from https:/ / www.wola.org/analysis/cicig-textof-the-agreement-between-the-united-nations-and-the-state-of-guatemala-on-the-establishment-of-an-international-commission-against-impunity-in-guatemala /

Woltke, Gabriel. 2018, September 4. “The 'Moralazo' Coup d'Etat Is Just a Matter of Time in Guatemala - Nómada, Guatemala." Nomada. Retrieved 15 July 2019 from https:/ / nomada.gt/pais/la-corrupcion-no-es-normal/the-moralazo-coup-detat-is-just-amatter-of-time-in-guatemala/

Woodin, Hayley. 2018, December 12. "B.C. Firm Seeks to Reopen Troubled Guatemalan Mine." Business in Vancouver. Retrieved 15 July 2019 from https:/ / doi.org/article/2018/12/ bc-firm-seeks-reopen-troubled-guatemalan-mine

World Bank. 2019. World Bank Databank. Retrieved 7 February 2019 from https:/ / data.worldbank.org/country/guatemala

World Bank. 2019. Guatemala Panorama General. Retrieved 30 May 2019 from http://www. bancomundial.org/es/country/guatemala/overview

Yagoub, Mimi. 2016, February 11. "Why Does Latin America Have the World's Highest Female Murder Rates?" Insight Crime. Retrieved 15 July 2019 from https://www.insightcrime.org/news/analysis/why-does-latin-america-have-the-world-s-highest-female-murder-rates / 
Received: June 1, 2019

Accepted: August 18, 2019

Dr. Brannum is the Program Director for International Relations and Global Security at the American Public University System. Her research focuses on human security, women's health security, and conflict resolution. Email: KBrannum@apus.edu 